\title{
Anatomical variation of obturator vessels and its practical risk: a case report from an anatomic study
}

\author{
Variação anatômica de vasos obturatórios e seu risco prático: relato \\ de caso de um estudo anatômico
}

\author{
Somayaji Nagabhooshana, Venkata Ramana Vollala, Vincent Rodrigues, Seetharama Bhat, \\ Narendra Pamidi, Stany Wilfred Lobo*
}

\begin{abstract}
Obturator artery is frequently a branch of anterior division of the internal iliac artery. It has drawn attention of pelvic surgeons, anatomists and radiologists because of the high frequency of variations in its course and origin. The obturator vein is usually described as a tributary of the internal iliac vein. During routine dissection classes to undergraduate medical students we have observed obturator artery arising from external iliac artery, obturator vein draining into external iliac vein, communicating vein between obturator vein and external iliac vein and inferior epigastric artery arising from the obturator artery. The anomalous obturator vessels and inferior epigastric artery in the present case may be in a dangerous situation in pelvic surgeries that require dissection or suturing along the pelvic rim. Developmental reasons and clinical significances of the variations are discussed.
\end{abstract}

Keywords: Obturator vessels, inferior epigastric artery, anatomical variation, complications.

\section{Introduction}

Obturator artery, a branch of anterior division of the internal iliac artery, normally runs anteroinferiorly on the lateral pelvic wall to the upper part of the obturator foramen, and leaves the pelvis via the obturator canal, where it divides into anterior and posterior branches to supply the medial compartment of the thigh. ${ }^{1}$

In the pelvis the obturator nerve is frequently above the artery and the obturator vein below it. ${ }^{1}$ Therefore, the common frequency of anatomical variations turns the attention toward pelvic medical professionals interested in this topography, such as surgeons, anatomists and radiologists. In addition, the origin of obturator

\section{Resumo}

A artéria obturatória é muitas vezes um ramo da divisão anterior da artéria ilíaca interna. Ela tem chamado atenção de cirurgiões pélvicos, anatomistas e radiologistas devido à alta freqüência de variações em seu trajeto e origem. A veia obturatória é geralmente descrita como uma tributária de veia ilíaca interna. Durante aulas de dissecação para estudantes de medicina, observamos a artéria obturatória surgindo a partir da artéria ilíaca externa, veia obturatória drenando para a veia ilíaca externa, veia comunicante entre a veia obturatória e a veia ilíaca externa e artéria epigástrica inferior surgindo a partir da artéria obturatória. Os vasos obturatórios anômalos e a artéria epigástrica inferior no presente caso podem se encontrar em situação perigosa em cirurgias pélvicas que exigem dissecação ou suturas ao longo da borda pélvica. Discutem-se as causas de desenvolvimento e a significância clínica das variações.

Palavras-chave: Vasos obturatórios, artéria epigástrica inferior, variação anatômica, complicações.

artery has been documented in $41.4 \%$ of cases from the common iliac or anterior division of internal iliac, in $25 \%$ from inferior epigastric, in 10\% from superior gluteal, in $10 \%$ from interior gluteal/internal pudendal trunk, in $4.7 \%$ from inferior gluteal, in $3.8 \%$ from internal pudendal and in $1.1 \%$ from external iliac artery. ${ }^{2}$ In very rare occasions, it may come from the posterior division of the internal iliac artery. ${ }^{3}$

The obturator vein generally begins in the proximal adductor region and enters the pelvis via the obturator foramen, runs posterior and superiorly on the lateral pelvic wall below the obturator artery and ends in the internal iliac vein. ${ }^{1}$

* Department of Anatomy, Melaka Manipal Medical College (Manipal Campus), Manipal University, Manipal, Karnataka, India.

No conflicts of interest declared concerning the publication of this article.

Manuscript received Apr 16, 2008, accepted for publication Jul 9, 2008. 
The inferior epigastric artery normally arises from the external iliac artery posterior to the inguinal ligament. However, the inferior epigastric artery sometimes arises from the femoral artery, or occasionally from the external iliac artery associated with an aberrant obturator artery, and it rarely originates from obturator artery. ${ }^{1}$

\section{Method}

This case report aims at publishing, from an anatomical dissection at Melaka Manipal Medical College, Manipal, India, a right variation related to obturator vessels of a 60 -year-old female cadaver. The variation was observed by the professor during routine dissection classes to undergraduate medical students. The dissection was carried out according with the instructions of Cunningham's manual of practical anatomy. ${ }^{4}$ The pelvis was divided into two equal halves by cutting through the pubic symphysis and the sacrum and coccyx. The section divided the bladder through the internal urethral orifice, then passed through the uterus and vagina and divided the rectum longitudinally. Then the peritoneum was removed from the bladder, uterus and lateral pelvic wall of each half of the pelvis. The internal iliac vessels and their branches and tributaries were followed. When the obturator artery was not found arising from the internal iliac artery, the external iliac artery was examined. The bodies were preserved by the injection of a formalin-based preservative ( $10 \%$ formalin) and stored at $-4{ }^{\circ} \mathrm{C}$.

\section{Result}

During the anatomical approach we found that the obturator artery arising from the external iliac artery gave origin to the inferior epigastric artery, ran superficially to the external iliac vein close to the femoral ring, crossed the pelvic upper limit and went down vertically behind the superior pubic ramus on the anterior pelvic wall to enter the obturator canal. Additionally, the obturator vein accompanied the obturator artery below it and drained into the external iliac vein. Furthermore, a small communicating vein was also seen between the obturator vein and the external iliac vein (Figure 1). On the other hand, the left half of the pelvis was normal.

\section{Discussion}

The superior border of the iliopubic ramus is an area of considerable concern for a variety of surgical subspecialists, as it serves as an anchoring site for inguinal and femoral hernia repairs. ${ }^{5}$

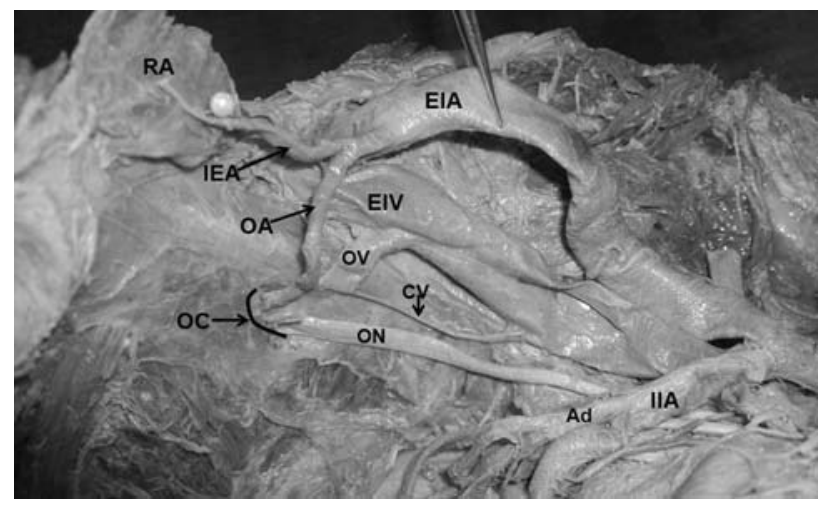

$\mathrm{Ad}=$ anterior division of the internal iliac artery $\mathrm{CV}=$ communicating vein; EIA = external iliac artery; EIV = external iliac vein; IEA = inferior epigastric artery; IIA = internal iliac artery; $\mathrm{OA}=$ obturator artery; $\mathrm{OC}=$ obturator canal; $\mathrm{ON}=$ obturator nerve; $\mathrm{OV}=$ obturator vein; $\mathrm{RA}=$ rectus abdominis.

Figure 1 - Dissection of anomalous obturator vessels on the right half of the pelvis

Surgeons operating on the lower abdomen and pelvis often retract the abdominal muscles laterally placing pressure on the lateral pelvic walls. Thus, a complete understanding of the anatomy of this area is critical. ${ }^{5}$

The obturator artery has been documented to be arising from all possible neighboring arteries, i.e., common iliac, external iliac, from any branch of internal iliac in either sex. ${ }^{2}$ Indeed, the commonest type of variation is the anastomosis between pubic branches of obturator artery of internal iliac origin and inferior epigastric artery which originates from the external iliac artery. ${ }^{2}$

Of these, only in $30 \%$ of cases this anastomosis opens up to become accessory obturator artery instead of the normal branch from the internal iliac artery. ${ }^{1}$ Otherwise, Bergman et al. have documented that the obturator artery arising from the external iliac artery can occur in only $1.1 \%$ of cases in the Western population. ${ }^{2}$ The relevance of this paper is to draw attention to those engaged in interventional maneuver into the human pelvis, as a variant obturator vessel can be inadvertently cut and result in very serious complications, for example, during femoral ring procedures or laparoscopic interventions. ${ }^{6}$

The obturator artery arises comparatively late in development from a plexus which in turn is joined by 
the axial artery of lower limb that accompanies the sciatic nerve. ${ }^{7}$ It is currently accepted that the anomalies affecting the arterial patterns of the limbs are based on an unusual selection of channels from primary capillaries. The most appropriate channel enlarges, whilst others retract and disappear, thereby establishing the final arterial pattern classified as "normal." "

In such case, persistence of vascular channels in relation to the external iliac artery might have resulted in giving rise to obturator artery, whereas the vascular channels related to the anterior division of the internal iliac artery destined for the obturator artery were obliterated.

Standard anatomy textbooks describe the origin of the inferior epigastric artery in detail and give a brief description of its course. A number of papers have studied the anatomy of the inferior epigastric artery more closely. Variability of the origin of the inferior epigastric artery has been described. Seventy-five lower limb dissections by Jakubowicz \& Czarniawska-Grzesinska showed the inferior epigastric artery originating from the external iliac artery above the inguinal ligament in $76 \%$ of cases, behind the ligament in $12 \%$ and from the femoral artery below the ligament in $8 \%$. In $4 \%$ of cases, the inferior epigastric artery came off a common trunk with an abnormal obturator artery. ${ }^{6}$

\section{Conclusion}

The present study described anatomical variations of obturator vessels that could be a cause of serious medical interventions.

\section{References}

1. Standring S. Gray's anatomy. 39th ed. London: Elsevier Churchil Livingstone; 2005. p. 1101, 1361.

2. Bergman RA, Thompson SA, Afifi AK. Compendium of human anatomic variations. Munich: Urban and Schwarzenberg; 1988. p. 84.

3. Kumar D, Rath G. Anomalous origin of oburator artery from the internal iliac artery. Int J Morphol. 2007;25:639-41.

4. Romanes GJ. Cunningham's manual of practical anatomy. In: Thorax and abdomen. 15th ed. Oxford: Oxford University; 1996. vol. 2. p. 214-5, 232.

5. Gilroy AM, Hermey DC, Dibenedetto LM, Marks SC Jr., Page DW, Lei QF. Variability of the obturator vessels. Clin Anat. 1997;10:328-32.

6. Jakubowicz M, Czarniawska-Grzesiñska M. Variability in origin and topography of the inferior epigastric and obturator arteries. Folia Morphol (Warsz). 1996; 55:121-6.

7. Sanduno JR, Roig M, Rodriguez A, Ferreira B, Domenech JM. Rare origin of the obturator artery, inferior epigatric and femoral arteries from a common trunk. J Anat. 1993;183(Pt 1):161-3.

8. Fitzgerald MJT. Human embryology. New York: Harper \& Row; 1978. p. 38-56.

Correspondence:

Venkata Ramana Vollala

Department of Anatomy

Melaka Manipal Medical College (Manipal Campus)

Manipal University

576104 - Manipal, Karnataka State - India

Tel.: +91-820-292-2642, +91-820-257-1905

E-mail: ramana.anat@gmail.com

\section{Aviso aos ex-residentes}

Se você foi residente até 2007 e ainda não está inscrito em sua Regional, procure regularizar sua situação para passar a receber o J Vasc Bras imediatamente, sem qualquer ônus. Ajude a manter o cadastro da SBACV atualizado. 